\title{
Together as One: Shared Leadership Between Managers
}

\author{
Marianne Döös ${ }^{1}$ \\ ${ }^{1}$ Department of Education, Stockholm University, Sweden \\ Correspondence: Marianne Döös, Department of Education, Stockholm University, SE-10691, Stockholm, \\ Sweden. Tel: 46-8-163-159. E-mail: marianne.doos@edu.su.se
}

Received: June 1, 2015

Accepted: June 18, 2015

Online Published: July 22, 2015

doi:10.5539/ijbm.v10n8p46

URL: http://dx.doi.org/10.5539/ijbm.v10n8p46

\begin{abstract}
The focus of the current paper is the formally shared leadership between managers. Position-sharing within pairs of managers demonstrates an alternative way of organising leadership within a managerial position. This paper aims to contribute knowledge about how to understand the phenomenon of formally shared leadership between managers, and to suggest concepts for its different forms. In the research literature, a range of different terms is used and it is difficult to see how or when this variation in labels is useful. Shared leadership between managers is here studied in relation to three perspectives: organisational structure, managers' experiences, and tasks and responsibilities. Future research has several questions left to answer in order to further understand the relatively widespread but under-researched issue of shared leadership between managers.
\end{abstract}

Keywords: shared leadership, managerial position, experience, organisation, work task

\section{Introduction}

The collective nature of leadership is a topic that has increasingly been discussed during the last decade, and the focus on leadership as being shared and distributed is part of this trend (e.g., Bolden, 2011; Crevani et al., 2007; Ensley et al., 2006; Konu \& Viitanen, 2008; Thorpe et al., 2011; Ulhøi \& Müller, 2014). This paper draws attention to the shared leadership between formally appointed managers, particularly at the low and middle management levels. Position-sharing within pairs of managers demonstrates an alternative way of organising leadership within a managerial position. This two-person instance is a "special case of shared leadership" (Pearce \& Conger, 2003a, p. 8). However, such leadership cooperation is reported about from a number of countries (e.g., Bunnell, 2008; Eckman, 2006; Rosengren \& Bondas, 2010) and is described in business-specific case studies in, for example, the banking sector (Johne \& Harborne, 2003) and the arts (de Voogt, 2006; Järvinen et al., 2013). Two sectors show a more recurring interest in shared leadership between managers: co-principalship within the education sector (e.g., Court, 2003; Eckman, 2007; Gosling et al., 2009; Gronn \& Hamilton, 2004), and shared leadership as partnerships within the health care sector (e.g., Rosengren et al., 2010; Steinert et al., 2006; Vinell, 2013). Yet there is a gap in the research literature about how to define the phenomenon of shared leadership between managers in relation to organisational structure, work tasks and the fundamentals for success. Furthermore, there is no stable conceptualisation of the phenomenon and the forms it takes in organisations. The focus of this paper is to use data from two qualitative studies of four and seven sharing pairs respectively in order to bring clarity to the phenomenon of shared leadership between managers and suggest concepts for its different forms. As the concern of the current paper is the formally shared leadership between managers, the wider and more frequent use of shared leadership as an issue of leadership distribution for increased participation and empowerment will be addressed, but is not in the centre of attention. The dynamic mutual influence processes that are characteristic of shared leadership (Pearce, 2004) are inherent also in teams of two or three managers that work together in sharing a managerial position. Managerial position-sharing may also be of importance to democratic organisational influence processes (Döös et al., 2003a; Wilhelmson \& Döös, 2014).

\section{Previous Research and Shared Leadership Concepts}

The standard model of formal leadership is to appoint one manager to one managerial position. This standard was coined in Henri Fayol's rule (1916) of 'only one manager'- a rule he described as indispensable. His concern reveals the existence of shared leadership among managers in the early 1900s as his rule was drawn up in the light of an explicit warning that "double leadership unfortunately [is] frequently existing and causes great damage to large and small businesses" (p. 47). In fact, shared leadership between two leaders is a phenomenon 
that does have a long history (Griffey \& Jackson, 2010; Sally, 2002; Wistrand, 1978). Sally (2002) and Wistrand (1978) explain that shared leadership was being practised in ancient Rome, between the two highest officers of state: the consuls. In the Roman Republic, the consuls shared power at the apex of a power-sharing system in which every official had to have a colleague with equal authority. Furthermore, O'Toole et al. (2002) remind us that the idea of singularity of leadership is a myth, since even the most written-about solitary leaders in history were supported by teams of equally adept people.

From research into today's working life, there is empirical evidence that managerial positions are successfully shared (e.g., Choi et al., 2012; Döös et al., 2003b; Eckman, 2007; Erlingsdóttir, 2010; Gronn \& Hamilton, 2004; O'Toole et al., 2002; Rosengren \& Bondas, 2010; Wilhelmson et al., 2006). Also, shared leadership between managers has, in Sweden, been found to exist broadly in working life and thus cannot be ignored as anecdotal (Döös et al., 2012). However, we still witness both ignorance of and resistance to the idea of shared leadership within a managerial position (e.g., Court, 2004; Döös et al., 2013; O’Toole et al., 2002). Sweden's new Education Act is a recent example, as it forbids school principals to formally share leadership on an equal basis; each so-called school unit has to have only one principal (Wilhelmson \& Döös, 2013). This motivates a discussion about how to conceptualise the phenomenon and its different forms.

Within the academic field of leadership, it has been suggested that new conceptual frameworks are needed (Bolden et al., 2011; Yukl, 2009). Yukl (2009) calls for a theory that may help to understand leaders' potential influence on organisational learning, while Bolden et al. (2011) call for theories and ways of thinking to suit a time characterised by ambiguity and unclear connections, where hierarchical relationships are less valid. They argue that the key to such development is to go outside the silos and boundaries between disciplines and conceptual paradigms. In particular, they highlight the idea of leadership as a shared process between people in organisations. Döös et al. (2013) argue that shared leadership is an example of learning-oriented leadership (Wilhelmson et al., 2013) in that the introduction of sharing managers in an organisation brings about new conditions for everyday work-integrated learning (Ellström, 2001) both for the managers themselves and for their co-workers (Note 1). Learning-oriented leadership is defined as intervening in the experiential learning processes integrated into people's everyday work tasks ( Doos et al., 2015).

In the research literature, a wide variety of different concepts reflect a multitude of approaches to collective and shared forms of leadership (Ulhøi \& Müller, 2014). In the specific case of shared leadership between managers, a range of different terms are used: shared leadership (Pearce \& Conger, 2003a), distributed leadership (Bunnell, 2008), co-leadership (Heenan \& Bennis, 1999), joint leadership (Wilhelmson, 2006), co-principalship (Eckman, 2007), dual leadership (Järvinen et al., 2013), two-getherness (Rosengren \& Bondas, 2010), leading in pairs (Alvarez et al., 2007), and leadership couple (Gronn, 1999). It is often difficult to see how or when this variation in labels is useful; Bolden (2011) finds that there is a relatively unstable usage of these concepts that varies over time, between countries, and also between sectors. Döös and Wilhelmson (2003) present a tentative categorisation of different forms of shared leadership between managers. The combination of jointly held or divided work tasks and responsibility/authority produced four categories (see Table 1).

Table 1. Four tentative categories of shared leadership between managers

\begin{tabular}{lll}
\hline Joint vs. Divided & Work tasks: joint & Work tasks: divided \\
\hline Joint responsibility/authority & Joint leadership & Functionally shared leadership \\
Divided responsibility/authority & Shadow leadership & Other forms (e.g., matrix leadership) \\
\hline
\end{tabular}

Joint leadership is characterised as being practised by full-time managers, who have the same managerial mandate and together assume responsibility, share power (and its responsibilities), have joint authority and also joint work tasks. It is characterised by equality and merged work tasks; the managers lead together as equals according to both the terms of their appointment by the organisation and in the day-to-day reality of their work practices. Neither is subordinate to the other in joint leadership. In shadow leadership, both managers also work to a large extent with the same issues; their work tasks are mainly joint in nature. However, there is a hierarchical difference concerning formal decision-making when it comes to issues of formal responsibility and authority, which may also signal differences in status in relation to employees and customers. Shadow leadership is seen as a densification of a cooperative arrangement between a manager and his/her assistant manager. Despite the formal hierarchy, the sharing managers regard each other as equals and practice joint responsibility and joint authority. This category comes close to Heenan and Bennis' (1999) co-leadership. Functionally shared 
leadership is characterised by the managers together assuming responsibility for the managerial whole, but with clearly divided work tasks. For example, one might run the production on a day-to-day basis, while the other deals with the finances. One is not subordinate to the other and; they are on the same hierarchical level. The category other forms relates to the cases where some densification of managerial cooperation does exist, although both responsibility/authority and work tasks are divided. This final category is characterised by a wish to create a common whole, despite everything essentially being divided.

In this paper, the decision is to use shared leadership as a broad category with joint leadership as an empirically identified sub-category. One reason to choose the term shared is that it embraces, but is not restricted to, pair leadership. Thus, the two-person case is included (Pearce \& Conger, 2003a), which is the commonest number of sharers among managers who also share in larger constellations (Döös et al., 2012). In addition, shared is open to findings from studies that point to the potential of sharing managers to empower, and thereby share leadership, also with their co-workers (Döös et al., 2003a; Erlingsdóttir, 2010).

Shared leadership between managers is here theoretically conceived as both a) a potential offshoot within hierarchical work organisation theory (e.g., Bratton, 2010) in the work of managers (Tengblad, 2012), where shared leadership generally is not mentioned at all, and b) as part of theory concerning the distribution of leadership (Pearce \& Conger, 2003b). In the first sense, shared leadership could be linked to formal work organisation issues such as task division, co-ordination, and control. For example, how work tasks are divided and co-ordinated is different when managerial positions are manned held by two or more managers (Döös et al., 2013; Vinell, 2013). When shared leadership between managers is instead understood with the help of distributed leadership theory, the focus shifts to the interaction between the sharing managers. Pearce and Conger (2003a) depict the sharing of leadership between two managers as a special instance of shared leadership-the two-person case. When shared leadership is viewed from the theoretical perspective of distributed leadership (Pearce \& Conger, 2003b), the focus moves to how leadership takes place inside the leadership team, i.e., between the two sharing managers, depending on the issue or situation. Hence, it becomes important to understand how sharing is enacted, i.e., how they take turns leading each other. Referring to Pearce (2004), the case where managers share one managerial position implies a kind of cooperation that "entails a simultaneous, ongoing, mutual influence process within a team that is characterized by "serial emergence"" (p. 48). Empirical studies show both how sharing managers aim to empower co-workers (Erlingsdóttir, 2010; Wilhelmson \& Döös, 2009) and how they share tasks within the leadership (Döös et al., 2003b) where they lead each other as well as their co-workers. Thus, and in partial contrast to how Choi (2009) defines shared leadership, this paper argues that shared leadership occurs both within a position in a hierarchy, and emphasises lateral peer influence.

\section{Aim and Research Questions}

The aim of this paper is to contribute knowledge about how to understand the phenomenon of formally shared leadership between managers, and to suggest concepts for its different forms. Four questions are addressed:

- How do the shared managerial positions relate to organisational structure?

- How do the sharing managers describe the ground on which they stand together?

- How do the managers share tasks and responsibilities: on an everyday basis and in terms of their mission as a whole?

- How may forms of shared leadership between managers be conceptualised?

\section{Methods}

Empirical material from two qualitative studies is here used and combined in order to shed light on shared leadership between managers. Data come from 11 sharing-pairs of managers in different types of activities (see Table 2).

Study 1. This first study was explorative and investigated the potential of shared leadership between managers. It was prompted by a curiousness based on having met a shared-leadership pair that had been successful in the leading of organisational change, and on the success of Sweden's national football coaches, who shared leadership on equal terms and took the team to the final tournaments of the European Championship and World Cup. This study identified the existence of successful cases of pair leadership and explored the managers' accounts of their cooperation processes. It was a positive selection of pairs that were documented as being successful in their leadership. Data was collected through in-depth interviews with four sharing-pairs from four different types of organisation (telecom product development, management consulting, communications, and the men's national football team). The interview guide covered individual background, how the sharing started, organisational activity, togetherness and sharing (process and outcome), power, context, work and leisure time, 
and the process of exiting shared leadership. The interviews were pair interviews. For the telecom pair, individual interviews were also used since this pair also participated in a study of organisational change(Wilhelmson\& Doos, 2009). The organisations varied in size from 20-220 people. The telecom and management-consulting managers led units within a large organisation, whereas the communication managers were managing directors of a small, private firm. The duration of managerial position sharing was 5-7 years at the time of the study. (Doos et al., 2003b).

Study 2. This second study was based upon the results of Study 1 and was a collaboration with a municipal competence development programme, where the sharing of leadership was seen by the municipality as a way of organising sustainable conditions for managers. Seven pairs were chosen for participation in the programme and all were included in the study. The data were collected in individual in-depth interviews with 14 managers (comprising the seven shared-leadership pairs) within one large municipal organisation, including managers within elderly care, technical administration, two pre-schools, a school, a library, and a fire brigade. A similar interview guide as in Study 1 was used and also a checklist of questions based upon the results from Study 1. Follow-up pair interviews were done after one year to see how the leadership cooperation had continued. The number of people who were directly subordinate varied from 15-120. And the number of years they had been sharing with each other varied between 0.5-12 (Wilhelmson et al., 2006). The results supported the findings from Study 1 , and identified additional nuances and variations regarding how to understand the fundamentals of sharing, and how work tasks and responsibilities may be divided between the managers. Study 2 identified differences in how sharing relates to organisational structure.

Table 2. Overview of the sharing-pairs in the two studies

\begin{tabular}{|c|c|c|c|c|c|}
\hline Activity of organisation & $\begin{array}{l}\text { Years of } \\
\text { sharing }\end{array}$ & Male/female & $\begin{array}{l}\text { No. employees in the } \\
\text { org }\end{array}$ & $\begin{array}{l}\text { No. of directly } \\
\text { subordinated }\end{array}$ & Study \\
\hline Telecom product development & 5 & $\mathrm{~m} / \mathrm{f}$ & 220 & - & 1 \\
\hline Management consulting & 5 & $\mathrm{f} / \mathrm{f}$ & 60 & - & 1 \\
\hline Communications & 7 & $f / f$ & 20 & - & 1 \\
\hline National football team & 6 & $\mathrm{~m} / \mathrm{m}$ & 35 & - & 1 \\
\hline Elderly care & 11 & $\mathrm{f} / \mathrm{f}$ & - & 40 & 2 \\
\hline Technical administration & 7 & $\mathrm{~m} / \mathrm{m}$ & - & 15 & 2 \\
\hline Pre-school & 1 & $\mathrm{f} / \mathrm{f}$ & - & 45 & 2 \\
\hline Pre-school & 12 & $\mathrm{f} / \mathrm{f}$ & - & 50 & 2 \\
\hline School & 11 & $\mathrm{f} / \mathrm{f}$ & - & 120 & 2 \\
\hline Library & 7 & $\mathrm{f} / \mathrm{f}$ & - & $30+30$ & 2 \\
\hline Fire brigade & 0.5 & $\mathrm{~m} / \mathrm{m}$ & - & 90 & 2 \\
\hline
\end{tabular}

In both studies, the data analysis mainly followed a timeline model that structured the information in a way that facilitated the identification of similarities and differences: how and why the sharing started; work and cooperation processes (including the distribution of responsibility, authority, work tasks, mission) during different phases (start, mature phase, final); the reasons to continue sharing; preconditions; possibilities and difficulties, both between the leaders and in relation to subordinates and superiors; outcomes; ending, and afterwards. For each study, all interviews were first analysed separately and then related to the others in a cross-case analysis.

\section{Results}

In this section, three empirically based perspectives characterizing the sharing of leadership among managers are presented: the organization structural perspective, the experience perspective, and the task perspective. Together they clarify the phenomenon of sharing managers and what constitutes such leadership. First, the organization structural perspective clarifies the relation between the sharing pair of managers and the organizational unit or units they lead together. Second, the experience perspective concerns the bedrock of the phenomenon of shared leadership, i.e. the characteristics that form an experience of sharing a common whole that they as managers lead together. Finally, the task perspective contributes knowledge about processes of organizing the shared leadership in terms of the managerial responsibility and work tasks.

According to both studies, shared leadership between managers concerns bringing about a comprehensible and manageable whole, and taking responsibility together for this whole. This applies to full-time managers' close cooperation and responsibility-taking, rather than to occurrences where there are two part-time managers who, in 
a technical sense, share the same position. The sharing-pairs used metaphors such as marriage and parenthood to describe their sharing. Some also stressed that, as in marriage, there are ups and downs, but that the important thing is whether you want to continue living together at work.

The emergence of shared leadership was, in both studies an informal process. People started to cooperate, and it was not until later that some began to strive towards being formally recognised as sharing managers in their organisation and so be recognised as equals in terms of position and formal decision-making. There were cases where the managers applied for a position together and were both employed on a full-time basis as sharing managers of a unit. Thus, the origin of these managerial pairs stemmed from a mutual identification of shared values and seeing the other as a potential person with whom to work closely together. In one case, the mutual selection was actually made as a result of an enforced leadership cooperation, where one substituted for the other because of a burnout-related sick leave. After this less-than-ideal start, these managers did choose one another, and took a common initiative so that they would together be appointed to lead ten departments in two large pre-schools.

\subsection{Sharing and Organisational Structure}

The empirical data showed that there were basically two types of sharing possibilities in relation to organisational structure: it was either a situation of having one unit with staff and a budget in common, or having one's own unit and cooperating across unit boundaries. Thus, two models of sharing were identified concerning the relation to the formal organisational structure: Model A and Model B (see Figure 1). In Model A, either one or both can be the appointed manager, either on an equal basis or with one formally superior to the other. In Model $\mathrm{B}$, the units exist alongside each other in the organisational structure, and each manager is, therefore, formally responsible only for his/her own unit.

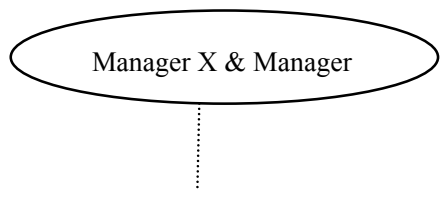

Org. Unit

Operations

Staff

Budget

Model A

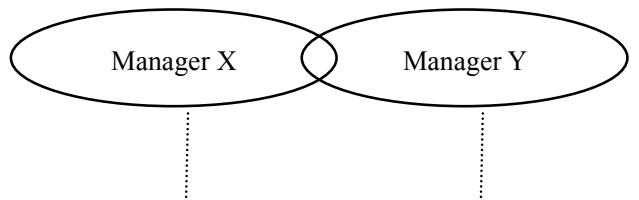

Org. Unit

Operations

Org. Unit

Staff

Budget

Operations

Staff

Budget

Figure 1. Two basic models of sharing as related to organisational structure.

Such structural differences in the sharing posed fundamentally different questions concerning cooperation. Those sharing a managerial position within one organisational unit described work tasks and managerial responsibility as joint undertakings. These managers' focus was upon how these joint undertakings were to be conducted and distributed between them. Two examples:

In this mission, we feel that we have a joint responsibility to make things work well, so it feels safe to talk everything through. (Pre-school pair, Model A).

We work with the same things but we swap every second month. This month, I am in inner command and run the rescue center. And then, next month, I'll be in outer command. (Fire brigade pair, Model A).

Managers sharing across an organisational boundary focused instead upon how closely to collaborate across unit boundaries. Their basic issue concerned which tasks could benefit from cooperation, how close the cooperation should be, and whether or not to see all staff as a whole and organise staff meetings on that basis. When the starting position is that everything is de facto formally separate, one issue may be whether to stay with a more casual level of cooperation or treat the staff as a unified whole and also flexibly enter into each other's budgets. One pair had a formal arrangement to work within each other's budgets: 
Formally, it has to be correctly entered in the books when you perform a task for a customer, entering expenses and so on. But, in practice, I can work in his budget and he in mine. Whatever is best at that moment. (Technical administration pair, Model B).

In other words, it is either about how to lead and organise shared responsibility for a common whole, or how to sew together what is laterally separate into some kind of whole, where the separation is at least partially erased.

\subsection{The Foundation on Which They Stand}

In analysing shared leadership between managers it emerged as essential to understand the related lived experiences of the managers. In both studies, without exception, the sharing managers drew attention to three points that, together, formed the bedrock of successful sharing:

- Non-prestige;

- Trust;

- Common values.

At first glance, assertion of such preconditions may come across as something of a cliché. However, what they meant in practice emerged strongly in day-to-day processes and commonplace conceptions. These included: processual ways of proceeding, where the leaders entered into and exited from common work tasks without compromising; a concrete, shared approach to planning, visualising and understanding; common interests and responsibilities reinforced by shared and thorough thinking and conversing on a day-to-day basis; joint preparations that enhanced opportunities for shared intuition and rapid action; utilising the benefits of being different and intentional advantage-taking of personal dissimilarity; the importance of joint analysis of setback and the shared joy of success; communication and exchange of ideas as keys to problem-solving and the resolution of difficulties; and, finally, the importance of being receptive to new ideas from others and spreading power beyond the pair, which partly discharged the management burden, created opportunities for co-workership, and strengthened operations. The interviewed managers stated that their close leadership created scope for forward-thinking and a long-term approach to work.

In addition to the three indispensable bedrock qualities-non-prestige, trust and shared values-co-leading managers stressed that it was of great value to be different, i.e., to have dissimilar qualities within the leadership. They mentioned their complementing competences and being different as important for successful cooperation. They made use of each other's competences and knowledge and, in so doing, became more stable together, with a broader competence and thus a greater benefit to the organization. Below, there follows both illustrating quotations and compilations of the meaning of each of the three bedrock qualities that together make up the fundamentals of shared leadership between managers.

Non-prestige. In a variety of ways, the sharing-pairs told stories that contained elements of non-prestige and also stressed the importance of being non-prestigious. They also gave reasons why this was important both in their cooperation and in their leading of others. Two quotations illustrate their non-prestige:

Neither of us finds it difficult to say things like "I'm not good at that" ... doing things together requires that you also see that I'm not the best at everything. (Communication pair).

When we've worked together [earlier], if, for example, there was a project with one as project manager and one assisting, it never was important which formal status we had; we simply worked together. (Management-consulting pair).

The compiled view of how non-prestige is shown in the thoughts and actions of the sharing-pairs follows here. The managers expressed that they:

- Were willing to share power and responsibility in both prosperity and adversity.

- Were uninterested in order of rank between themselves.

- Did not draw attention to themselves and wer concerned with individual glory.

- Included each other in successes.

- Interrupted one another and jumped freely in and out of each other's sentences, even in public.
- Intervened in and took over the other's task, even in front of co-workers.

- Worked side-by-side in projects with people who were formally subordinate.

- Did not pretend to one another.

- Criticised each other and each other's ideas.

- Were able to identify and admit their own shortcomings.

- Despite being good at a task still gave that task to the other when he/she wanted like it. 
Trust. When looking into how the managers talked about what they do and how they think, it was evident that non-prestige was related to their confidence in each other and each other's knowledge. A far-reaching, even complete, trust in each other was described:

She blazes the trail and I walk half a step behind, probably an unbeatable combination ... and absolute trust (Telecom-development pair).

And since I have a different view on things, it would never have been possible if [he] hadn't been so generous in giving up space and listening to this. It is very important to be generous, that there is room for confidence. (Telecom-development pair).

The following points compile the nature of the trust within the sharing-pairs:

- Trusting the other's intuition and presentiments.

- Having trust in the other's ideas.

- Trusting the other's solutions, even when they are drastic.

- Being tolerant - it is okay to fail.

- Being able to handle bad decisions and difficulties together.

- Standing up for the other's decision, even when not fully agreeing.

- Having solidarity with the other, and being 100 per cent loyal.

Common values in two respects. The third matter that emerged as necessary for leading successfully together was shared values. Shared values also constituted a foundation for the building of trust. These necessary common values concerned two equally important aspects: the goal and visions of the activity, and how to lead and treat human beings. Here are a few examples of how the leaders expressed their shared views:

We really feel that we can trust one-another, that we have the same core values. (Elderly care pair).

We think alike most of the time, since we stand on the same [value] ground. (School pair).

I felt that we were alike, that we shared a football philosophy. (National football team pair).

To be a leader is both how you think, and also what [co-workers] see daily, what you do and how you do things, and here we are quite similar. How to treat a client, how to deal with somebody you meet. How to talk in a project, how to talk on the phone-here, we're very similar. And I think that is good because it means that there is some norm (Communication pair).

Their shared values made them identify with one another from the start. A continuous joint building of their values made them tight and made it possible to smoothly alternate with each other in daily tasks. The shared values represent a basis that enabled them to progress in a united direction, while at the same time making use of their differences.

\subsection{The Sharing of Tasks and Responsibilities}

This section will outline how the managers shared tasks and responsibilities on an everyday basis and also in terms of their mission as a whole.

\subsubsection{Task-Sharing on an Everyday Basis}

When the managers spoke about how they shared their tasks on an everyday basis, they spoke of their leadership as shifting between working alone on a specific task and then getting together in a meeting - an occasion where responsibility for progressing the task could alternate between the two. It was common to stress the tasks as being joint responsibilities, and to take turns in doing different things; two quotations illustrate this type of alternating:

In practice, no matter what tasks lay ahead, we make a rough plan then divide the work between us so that one of us works out a more detailed suggestion. Then we get together again. All the time, we sort of go into and out of a kind of process activity. (National football team pair).

This accuracy, of which you have a bit more than I, could have turned to a weakness, if you had always been exposed to the financial and administrative tasks. (Management-consulting pair). 
The following points compile how joint leadership's tasks were thought of and carried out by the sharing-pairs:

- Regarded work tasks as a joint enterprise to share - instead of dividing them.

- Switched tasks between themselves, i.e. alternately working together and apart.

- Ensured that neither was stuck with a specific sort of task in the long-term, which would endanger joint responsibility.

- Had constant discussion and communication within the leadership, to be thought-out and talked-through.

- Joint analysis during setbacks, and shared the joy of success.
- Reached converging views instead of compromises.

- Had a concrete, shared approach to planning, visualising, and understanding.

- Made common preparations that created the ability to quickly and intuitively act in critical situations.

- Derived the common benefit from being different.

- Were receptive to new ideas of others and spreading power beyond the pair.

\subsubsection{Tasks and Responsibilities for the Mission as a Whole}

The sharing of tasks and responsibilities will now be dealt with in terms of the managers' mission as a whole. The way the managers described their sharing indicates that the issue of whether to divide or to have tasks in common makes a difference. All the managers in Study 1 worked in joint leadership, whether formal ( 3 cases) or informal (1 case). The four categories of shared leadership suggested by Döös and Wilhelmson (2003) were used to describe the sharing of the pairs in Study 2. The categorisation may be used as a map, but in practice it is common that sharing managers make their own mix of categories and also move between categories over time. In Study 2, the managers used these categories to understand their own sharing; some indicated that they worked mainly as joint leaders, whereas some mixed joint and functionally shared leadership, while some regarded themselves as leading jointly in practice, but on a formal basis in terms of shadow leadership (see Table 3).

Table 3. Seven managerial pairs' own classifications of the category of their leadership

\begin{tabular}{|c|c|c|c|c|}
\hline Joint leadership & $\begin{array}{l}\text { Mix of joint leadership } \\
\text { and functionally shared } \\
\text { leadership }\end{array}$ & $\begin{array}{l}\text { Shadow leadership } \\
\text { with joint leader-ship } \\
\text { practice }\end{array}$ & $\begin{array}{l}\text { Functionally } \\
\text { shared leadership }\end{array}$ & $\begin{array}{l}\text { Moving between four } \\
\text { categories when switching } \\
\text { between inner and outer posts }\end{array}$ \\
\hline Pre-school pair & Pre-school pair & School pair & Library pair & Fire brigade pair \\
\hline Elderly care pair & $\begin{array}{l}\text { Technical administration } \\
\text { pair }\end{array}$ & & & \\
\hline
\end{tabular}

Some of the sharing-pairs expressed a desire to have their shared leadership formally recognized by the organization in the interests of clarity, stability and efficiency. In some cases, the organisation had adjusted to the reality of sharing managers; in others, the sharers continued to compensate for organisational flaws and found ways to circumvent what they considered to be rigid organisational structures in order to create sustainable leadership.

\section{Discussion}

Shared leadership between managers has, in this paper, been related to organisational structure, to managers' experiences, and to tasks and responsibilities. The organisational structure perspective highlights the relationship between sharing managers and the organisational unit or units they lead together. The experience perspective identifies the bedrock of shared leadership - the characteristics that form and support an experience of sharing a common whole that the managers lead together. The qualities of this bedrock become the ground on which they stand together. Finally, the task perspective contributes a map of concepts (which-are further developed below) -and also the finding that task division is not necessarily the route to clarity and success. Thus, shared leadership between managers is a leadership issue that is found in many organisations either within an organisational unit or across an inner organisational boundary. It is built on the bedrock of trust, non-prestige and shared values. This bedrock is regarded as necessary for success. Contrary to many expectations, it is not a division of work tasks that brings about clarity, it is to regard tasks as joint and take turns in who does what.

The managerial pairs' experiences and reflections, when working in shared leadership, reveal a close and tightly 
knit relationship. Ongoing communication and exchange of ideas are essential in handling leadership tasks when they are shared. Dialogue within the leadership pair is something to which a solitary leader never has access. Such processes have been shown to contribute to interpretation, sense making, and learning that stabilise and bring nuances and complementary thinking to leadership tasks and contribute to the development of the involved managers (Wilhelmson, 2006). In accordance with other studies (e.g., Eckman, 2006; Rosengren \& Bondas, 2010), trust is stressed as a necessary condition for successful sharing. Newell and Swan (2000) suggest a typology with three different forms of trust: companion, competence, and commitment trust. In brief, these are explained by Bergh et al. (2011) as follows:

Companion trust refers to trust based on friendship and emotions. Competence trust is based on perceptions of another's skills and ability to perform a task. Commitment trust is based on agreements between interacting parties. (p. 20).

The ways the sharing-pairs expressed their experiences indicate that all three forms of trust were in place. As shown above, trust was also thought of as being related to the other two bedrock qualities of non-prestige and common values.

There is an often-heard argument that assumes that task division brings about clarity in the organisation, especially in relation to co-workers. In contrast, it is here worth noticing the identification of 'joint leadership' and the value of having tasks in common, and rotating them within the pair rather than dividing them between each other. When viewing through a lens of experiential learning theory (Döös, 1997; Kolb, 1984), it becomes comprehensible that working with the same tasks and thereby covering the full assignment roots both parties in similar day-to-day experiences. Division, by contrast, creates a gap between what managers learn on a daily basis, which means more time and effort is then required to sew the gap together through communication. This argument is in accordance with the experience of Eckman's (2006) co-principals, who explained that they had "deliberately chosen to experience all the components of the principalship" (p. 98).

\subsection{Shared Leadership}

Appearances can be deceptive when it concerns the word 'sharing', whose, ambiguity lies in its double meaning. To share something can signify either dividing it or keeping it whole and having mutual ownership. This also reflects the range of shared leadership from the more divided to the more joint forms. In order to learn from separate cases and future studies within the field of collective leadership, there is an urgent need to conceptualise and specify the sharing of leadership between managers. Hopefully, the bedrock qualities and the identified sub-categories of shared leadership in this paper are a contribution in that direction. A practical problem for researchers within this field is that the lack of conceptual accord makes the identification of relevant research harder. Therefore, I suggest the use of shared leadership as a standard keyword when publishing in order to facilitate this process. That said, the question of how to further conceptualise sub-categories of shared leadership between managers will now be examined.

Heenan and Bennis (1999) identify the important, yet formally subordinate, co-leadership as a person playing second-fiddle close to a formally appointed leader. Their co-leadership concept describes a partnership at the level of managing director, and is defined as "two leaders in vertically contiguous positions who share the responsibilities of leadership" (Vine et al., 2008, p. 340) and where "the only difference between a leader and a co-leader is the greater fame of No. 1 and the size of his or her compensation package" (Heenan \& Bennis, 1999, p. 263). This concept of co-leadership comes close to joint leadership in terms of how the leaders perceive each other and how work tasks are distributed. However, when it concerns issues of formal responsibility and authority, there is, in Heenan and Bennis' concept, a hierarchical difference that signals a difference in status. Formal joint leadership takes things one-step further as it pertains to the legitimised acts of equals.

This paper, in conceptualising sub-categories of shared leadership, proposes a new understanding. To the basis of the empirical data, and the concepts earlier accounted for in Table 2, inspiration is here added from a paper by de Voogt and Hommes (2007). whichleads to a partly novel categorisation. Four sub-categories of shared leadership between managers are suggested: two with formal hierarchic equality (joint leadership and functionally shared leadership) and two with formal subordination (invited leadership and distributed delegation of leadership) (see Table 4). Thus, the issue of formal equality has been sharpened by crossing hierarchy with task distribution. 
Table 4. The forms of shared leadership between managers: four suggested sub-categories

\begin{tabular}{lll}
\hline Hierarchy vs. task allocation & Merged tasks & Divided tasks \\
\hline Formal equality & Joint leadership & Functionally shared leadership \\
Formal subordination & Invited leadership & Distributed delegation of leadership \\
\hline
\end{tabular}

From Table 4, it follows that joint leadership is understood as complete cooperation, where formal hierarchic equality is in place and work tasks are merged. The concept of invited leadership was chosen in order to acknowledge the sub-category of shared leadership, where there is one official manager and where the lower ranking partner's share in decision making takes place "with the permission of the first" (de Voogt \& Hommes, 2007 , p. 2). When conceptualising sub-categories of sharing, invited leadership seems more appropriate than 'shadow leadership' (cnf. Table 2). The question of whether the formally subordinate manager stays in the shadows or not, will vary between cases. Functionally shared leadership is useful as a concept for cases with hierarchical equality but where managers have differing professional areas and daily tasks. This form of sharing has earlier been reported in studies of pairs, using terms such as dual leadership (e.g., Järvinen et al., 2013). Finally, distributed delegation of leadership is here used to recognise formal subordination in combination with delegating some specified work tasks to other people in the organisation.

\subsection{Conclusions and Future Research}

To conclude, sharing between managers may be of specific interest for future leadership development in the post-heroic bent that Alvesson and Sveningsson (2003) have described within the narrative of leadership as singular, and Crevani et al. (2007) used in defining leadership as a collective construction process. Shared leadership makes a difference to managers' and co-workers' interaction and learning, which explains why the issue of how to organise leadership is important. Joint leadership, in its far-reaching togetherness, deserves special interest.

Future research has several questions left to answer in order to further understand the relatively widespread (Döös et al., 2012) but under-researched issue of shared leadership between managers. Of particular interest is to further study the experiences of a 'multi-shared leadership' between nurse managers that has emerged as an organisational solution in highly specialised intensive health care (Vinell, 2013). When the shared managerial position involves four or even five managers difficulties seem to arise that may threaten the leadership qualities that have been identified for joint leadership in pairs. Regarding organisational structure, the recent Education Act in Sweden has introduced the term 'school unit' and states that each school and pre-school unit must have only one principal/manager. In the Swedish context, this points to a need to understand deeper the work processes and task division of the formally subordinate invited leadership as well as to research the sharing of leadership across organisational boundaries (Model B-type) as some schools now consist of two-three school units each lead by a principal who is not allowed to work too close to the other principal(s) of the same school. This organisational solution was introduced as a consequence of the recent Education Act and it is important to create more knowledge about it.

Hopefully, this paper contributes to moving perceptions of leadership towards a greater degree of pluralism, incorporating more collective solutions than does the currently dominant idea of singular leadership. It is no longer the case that a leadership position should routinely be assigned to one single leader. The issue of how leadership is organised needs to be opened up and reconsidered when assessing the results of leadership, its success, sustainability and value to the organisation. Finally, pluralism calls for qualified deliberation concerning when and how shared leadership-or solo leadership is appropriate. By not defining shared leadership between managers, and joint leadership in terms of the number of managers (using terms such as duo, two, couple or pair), the concepts are kept open for the further study of variations in forms and numbers of sharing managers.

\section{References}

Alvarez, J. L., Svejenova, S., \& Vives, L. (2007). Leading in pairs. MIT Sloan Management Review, 48(Summer 4), 10-14.

Alvesson, M., \& Sveningsson, S. (2003). Managers doing leadership: The extra-ordinarization of the mundane. Human Relations, 56(12), 1435-1459. http://dx.doi.org/10.1177/00187267035612001

Bergh, P., Thorgren, S., \& Wincent, J. (2011). Entrepreneurs learning together: The importance of building trust for learning and exploiting business opportunities. Int Entrep Manag J., 7, 17-37.

Bolden, R. (2011). Distributed leadership in organizations: A review of theory and research. International 
Journal of Management Reviews, 13, 251-269. http://dx.doi.org/10.1111/j.1468-2370.2011.00306.x

Bolden, R., Hawkins, B., Gosling, J., \& Taylor, S. (2011). Exploring leadership. Individual, organizational, and societal perspectives. Oxford: Oxford University Press.

Bratton, J. (2010). Organizational design. In J. Bratton, P. Sawchuk, C. Forshaw, M. Callinan \& M. Corbett (Eds.), Work and organizational behaviour (2nd ed., pp. 276-306). New York: Palgrave Macmillan.

Bunnell, T. (2008). The Yew Chung model of dual culture co-principalship: A unique form of distributed leadership. International Journal of Leadership in Education, 11(2), 191-210. http://dx.doi.org/10.1080/13603120701721813

Choi, S. (2009). The emergence of shared leadership from organizational dimensions of local government. International Journal of Leadership Studies, 5(1), 94-114.

Choi, S., Holmberg, I., Löwstedt, J., \& Brommels, M. (2012). Managing clinical integration: A comparative case study in a merged university hospital. Journal of Health Organization and Management, 26(4), 486-507. http://dx.doi.org/10.1108/14777261211251544

Court, M. R. (2003). Towards democratic leadership. Co-principal initiatives. International Journal of Leadership in Education, 6(2), 161-183. http://dx.doi.org/10.1080/1360312032000093944

Court, M. R. (2004). Talking back to New public management versions of accountability in education: A co-principalship's practices of mutual responsibility. Educational Management Administration \& Leadership, 32(2), 171-194. http://dx.doi.org/10.1177/1741143204041883

Crevani, L., Lindgren, M., \& Packendorff, J. (2007). Shared leadership: A postheroic perspective on leadership as a collective construction. International Journal of Leadership Studies, 3(1), 40-67.

De Voogt, A. (2006). Dual leadership as a problem-solving tool in arts organizations. International Journal of Arts Management, 9(1), 17-22.

De Voogt, A., \& Hommes, K. (2007). The signature of leadership: Artistic freedom in shared leadership practice. The John Ben Shepperd Journal of Practical Leadership, 2(1), 1-5.

Döös, M. (1997). The qualifying experience. Learning from disturbances in relation to automated production. Work and Health, Solna: National Institute for Working Life.

Döös, M., \& Wilhelmson, L. (2003). Shared leadership-a trend in the making? In C. von Otter (Ed.), Out or in in Swedish working life-researchers analyse and speculate about trends i future work. Working Life in Transition no 2003:8 (pp. 323-344). Stockholm: National Institute for Working Life (in Swedish).

Döös, M., Backström, T., Melin, M., \& Wilhelmson, L. (2012). Isolated cases or widespread practice? The occurrence of sharing managers in Swedish working life. Economics and Business Letters, 1(3), 23-36.

Döös, M., Wilhelmson, L., \& Backström, T. (2013). Shared leadership of managers in collaboration (2nd ed.). Stockholm: Liber. (in Swedish).

Döös, M., Johansson, P., \& Wilhelmson, L. (2015). Beyond being present: Learning-oriented leadership in the daily work of middle managers. Journal of Workplace Learning, 27(6), 408-425. http://dx.doi.org/10.1108/JWL-10-2014-0077

Döös, M., Wilhelmson, L., \& Hemborg, Å. (2003a). Contagious power-joint leadership as influence process. Ledmotiv(3), 58-71. (in Swedish).

Döös, M., Wilhelmson, L., \& Hemborg, Å. (2003b). Shared leadership as possibility. In L. Wilhelmson (Ed.), Renewal in Swedish workplaces (pp. 182-211). Stockholm: The National Institute for Working Life. (in Swedish)

Eckman, E. W. (2006). Co-principals: Characteristics of dual leadership teams. Leadership and Policy in Schools, 5, 89-107. http://dx.doi.org/10.1080/15700760600549596

Eckman, E. W. (2007). The co-principalship: It's not lonely at the top. Journal of School Leadership, 17(3), 313-339.

Ellström, P. E. (2001). Integrating learning at work: Problems and prospects. Human Resource Development Quarterly, 12(4), 421-435.

Ensley, M. D., Hmieleski, K. M., \& Pearce, C. L. (2006). The importance of vertical and shared leadership within new venture top management teams: Implications for the performance of startups. The Leadership 
Quarterly, 17(3), 217-231. http://dx.doi.org/10.1016/j.leaqua.2006.02.002

Erlingsdóttir, G. (2010). Managing change by Mumin's philosophy. Shared leadership in a primary health clinic. Paper presented at the 9th International Studying Leadership Conference (ISLC), Lund, Sweden.

Fayol, H. (1916). Administration industrielle et générale (Translation to Swedish in 2008 by Karin Holmblad Brunsson ed.). Stockholm: Santérus.

Gosling, J., Bolden, R., \& Petrov, G. (2009). Distributed leadership in higher education: What does it accomplish? Leadership, 5(3), 299-310. http://dx.doi.org/10.1177/1742715009337762

Griffey, E., \& Jackson, B. (2010). The portrait as leader: Commissioned portraits and the power of tradition. Leadership, 6(2), 133-157. http://dx.doi.org/10.1177/1742715010363207

Gronn, P. (1999). Substituting for leadership: The neglected role of the leadership couple. The Leadership Quarterly, 10(1), 41-62.

Gronn, P., \& Hamilton, A. (2004). A bit more life in the leadership: Co-principalship as distributed leadership practice. Leadership and Policy in Schools, 3(1), 3-35. http://dx.doi.org/10.1076/lpos.3.1.3.27842

Heenan, D. A., \& Bennis, W. (1999). Co-Leaders. The power of great partnerships. New York: John Wiley \& Sons, Inc.

Holmberg, I., \& Åkerblom, S. (2007). Primus inter pares. Leadership and culture in Sweden. In J. S. Chokar, F. Brodbeck \& R. J. House (Eds.), Culture and leadership around the world: The GLOBE book of in depth studies of 25 societies. New Jersey: Lawrence Erlbaum Associates, Inc.

Järvinen, M., Ansio, H., \& Houni, P. (2013). New dual leadership in Finnish theatres. Paper presented at the WORK 2013 Conference, 21-23 Aug 2013, Turku, Finland.

Johne, A., \& Harborne, P. (2003). One leader is not enough for major new service development: Results of a consumer banking study. The Service Industries Journal, 23(3), 22-39.

Kolb, D. A. (1984). Experiential learning. Experience as the source of learning and development. Englewood Cliffs, NJ: Prentice-Hall.

Konu, A., \& Viitanen, E. (2008). Shared leadership in Finnish social and health care. Leadership in Health Services, 21(1), 28-40. http://dx.doi.org/10.1108/17511870810845888

Newell, S., \& Swan, J. (2000). Trust and inter-organizational networking. Human Relations, 53(10), 1287-1328.

O'Toole, J., Galbraith, J., \& Lawler, E. E. I. (2002). When two (or more) heads are better than one: The promise and pitfalls of shared leadership. California Management Review, 44(4, Summer 2002), 65-83.

Pearce, C. L. (2004). The future of leadership: Combining vertical and shared leadership to transform knowledge work. Academy of Management Executive, 18(1), 47-57.

Pearce, C. L., \& Conger, J. A. (2003a). All those years ago. The historical underpinnings of shared leadership. In C. L. Pearce \& J. A. Conger (Eds.), Shared leadership. Reframing the hows and whys of leadership (pp. 1-18). Thousand Oaks: SAGE Publications.

Pearce, C. L., \& Conger, J. A. (Eds.). (2003b). Shared leadership. Reframing the hows and whys of leadership. Thousand Oaks: SAGE Publications.

Rosengren, K., \& Bondas, T. (2010). Supporting "two-getherness": Assumption for nurse managers working in a shared leadership model. Intensive and Critical Care Nursing, 26, 288-295. http://dx.doi.org/10.1016/j.iccn.2010.08.002

Rosengren, K., Bondas, T., Nordholm, L., \& Nordström, G. (2010). Nurses' views of shared leadership in ICU: A case study. Intensive and Critical Care Nursing, 26, 226-233. http://dx.doi.org/10.1016/j.iccn.2010.06.001

Sally, D. (2002). Co-leadership: Lessons from republican Rome. California Management Review, 44(4), 84-99.

Steinert, T., Goebel, R., \& Rieger, W. (2006). A nurse-physician co-leadership model in psychiatric hospitals: Results of a survey among leading staff members in three sites. International Journal of Mental Health Nursing, 15, 251-257. http://dx.doi.org/10.1111/j.1447-0349.2006.00431.x

Tengblad, S. (Ed.). (2012). The work of managers: Towards a practice theory of management. Oxford: Oxford University Press.

Thorpe, R., Gold, J., \& Lawler, J. (2011). Locating distributed leadership. International Journal of Management Reviews, 13, 239-250. http://dx.doi.org/10.1111/j.1468-2370.2011.00303.x 
Ulhøi, J. P., \& Müller, S. (2014). Mapping the landscape of shared leadership: A review and synthesis. International Journal of Leadership Studies, 8(2), 66-87.

Vine, B., Holmes, J., Marra, M., Pfeifer, D., \& Jackson, B. (2008). Exploring co-leadership talk through interactional sociolinguistics. Leadership, 4(3), 339-360. http://dx.doi.org/10.1177/1742715008092389

Vinell, H. (2013). Nurse manager experiences of multi-shared leadership: Possibilities and difficulties when more than two share the same chair. Master thesis, Stockholm: LIME, Karolinska institutet. (in Swedish).

Wilhelmson, L. (2006). Transformative learning in joint leadership. Journal of Workplace Learning, 18(7-8), 495-507. http://dx.doi.org/10.1108/13665620610693042

Wilhelmson, L., \& Döös, M. (2009). Sustainable heritage in a rapidly changing environment. In P. Docherty, M. Kira, \& A. B. Shani (Eds.), Creating sustainable work systems. Developing social sustainability (2nd ed., pp. 117-130). London: Routledge.

Wilhelmson, L., \& Döös, M. (2013). Leading jointly in schools and pre-schools. In O. Johansson \& L. Svedberg (Eds.), Leading towards the goals of schools (pp. 127-140). Malmö: Gleerups. (in Swedish).

Wilhelmson, L., \& Döös, M. (2014). Joint principalship: Co-principals working as equals and their democracy assignment. Paper presented at the International Conference on Organizational Learning, Knowledge and Capabilities (OLKC), April 23-24 2014, Oslo, Norway.

Wilhelmson, L., Döös, M., Backström, T., Bellaagh, K., \& Hanson, M. (2006). Perspectives on shared leadership in some local government activities. Experiences of 14 sharing unit managers, their co-workers and superiors.: Work Life Report 2006:50. Stockholm: Arbetslivsinstitutet. (in Swedish).

Wilhelmson, L., Johansson, P., \& Döös, M. (2013). Bridging boundaries: Middle managers' pedagogic interventions as technology leaders. In S. Wang, \& T. Hartsell (Eds.), Technology integration and foundations for effective leadership (pp. 278-292). Hershey: IGI Global. http://dx.doi.org/10.4018/978-1-4666-2656-0.ch016

Wistrand, E. (1978). Politik och litteratur i antikens Rom (2nd ed.). Göteborg: Paul Åströms förlag.

Yukl, G. (2009). Leading organizational learning: Reflections on theory and research. The Leadership Quarterly, 20, 49-53. http://dx.doi.org/10.1016/j.leaqua.2008.11.006

Note

Note 1. The term 'co-workers' in this paper refers to the staff subordinate to the managers. In the Swedish egalitarian workplace culture (Holmberg \& Åkerblom, 2007) the term subordinate is normally not used.

\section{Copyrights}

Copyright for this article is retained by the author(s), with first publication rights granted to the journal.

This is an open-access article distributed under the terms and conditions of the Creative Commons Attribution license (http://creativecommons.org/licenses/by/3.0/). 